\title{
Effect of the concentrations of maltogenic $\alpha$-amylase and fat on the technological and sensory quality of cakes
}

\author{
Noelia Soledad BEDOYA-PERALES ${ }^{1 *}$, Caroline Joy STEEL ${ }^{1}$
}

\begin{abstract}
The characteristics that define cake quality can be improved by the use of adequate ingredients and a correct balance of the formulation. Fat is used for its effect on softness and because it imparts flavor and calories. Enzymes such as maltogenic $\alpha$-amylase can also have a positive effect on cake texture during storage by decreasing amylopectin re-crystallization and thus delaying starch retrogradation providing longer-lasting crumb softness. The objective of this study was to determine the effect of different concentrations of maltogenic $\alpha$-amylase and fat on the technological and sensory characteristics of cakes. Therefore, balanced formulations with three different fat concentrations $(20,40$, and $60 \mathrm{~g} / 100 \mathrm{~g}$, based on the flour content) were used to evaluate the addition of maltogenic $\alpha$-amylase $(0,500$, and $1000 \mathrm{mg} / \mathrm{kg})$. Technological quality determinations were carried out on days 1, 7, 14, and 21 of storage. The best results in terms of cake quality (greater specific volume, higher crumb moisture content, lower crumb firmness, and greater sensory acceptance) were obtained with the combination of $20 \mathrm{~g} / 100 \mathrm{~g}$ fat and $1000 \mathrm{mg} / \mathrm{kg}$ maltogenic $\alpha$-amylase (based on the flour content), which proved to be an alternative to reduce the fat levels in the elaboration of this type of product.
\end{abstract}

Keywords: formulation balancing; cake quality; crumb firmness; retrogradation.

\section{Introduction}

In cake making, the formulation and balance of the ingredients are fundamental to ensure quality of the final product, and they can be evaluated by determining parameters such as volume, texture, moisture, and crumb structure among others (Sahin, 2008). Each ingredient has a specific function (Wilderjans et al., 2008; Indrani \& Rao, 2008) and can be grouped as follows: (i) those that provide strength and structure to the cake, such as flour and eggs; (ii) those that open the structure such as sugar, fat, and baking powder; and (iii) those that close the structure and reduce lightness, such as milk and water (the liquids). It is essential to use a formulation that has an adequate balance between ingredients that open the structure and those that close it (Bennion \& Bamford, 1997).

In general, formulations that are rich in fat and sugar are soft, but an excess of these ingredients can cause the products to crumble easily (Esteller et al., 2004). On the other hand, total removal of fat can change flavor, texture, lightness, softness, shape, and volume of cakes (Khalil, 1998; Sakiyan et al., 2004). According to the amount of fat added, cakes can be divided into two categories: cakes with high fat levels (pound cake) and those with low fat levels (chiffon or sponge cakes) (Sahi, 2008).

Regardless of the type of cake, in order to develop formulations that ensure products with desirable quality, additives such as emulsifiers and hydrocolloids can be included (Indrani \& Rao, 2008). However, enzymes are an interesting alternative to chemical additives since they are considered a food processing aid and are generally recognized as safe (GRAS), not remaining active in the product after baking
(Ronda et al., 2009). Enzymes, in general, are widely used in bakery products because they improve volume, flavor, aroma, softness, crumb structure, and increase shelf life (Lagrain et al., 2008; Guy \& Sahi, 2006), but little is known about their effects on cakes. Maltogenic $\alpha$-amylase is used in baking to allow for extensive hydrolysis of crystallizable amylopectin, preventing its recrystallization (retrogradation) during storage. This allows for conservation of the soft crumb characteristics, prolonging the shelf life (Goesaert et al., 2009a).

Considering the facts exposed, the objective of this study was to determine the effect of different concentrations of maltogenic $a$-amylase and fat on the technological (specific volume, moisture content, and instrumental texture) and sensory characteristics of cakes using balanced pound cake formulations.

\section{Material and methods}

\subsection{Materials}

The wheat flour used had the following characteristics: $12.40 \%$ moisture content, $9.52 \%$ proteins, $1.28 \%$ lipids, $0.57 \%$ ash, and $76.23 \%$ total carbohydrates (Bunge Alimentos S.A., Poço Grande, SC, Brazil). The fat used was TRI HS-LT low trans vegetable fat, specific for cakes (Triângulo Alimentos, Itápolis, SP, Brazil), and the enzyme was Spring Cake line maltogenic $\alpha$-amylase (Granotec do Brasil S/A, Curitiba, $\mathrm{PR}$, Brazil), consisting of a purified maltogenic $\alpha$-amylase from Bacillus stearothermophilus, produced by submerged fermentation of the microorganism Bacillus subtilis (minimum 
maltogenic $\alpha$-amylase activity: 48,000 UAMG/g). The remaining ingredients used to make the cakes are shown in Table 1.

\subsection{Cake making}

Table 1 shows the formulations used to make the cakes. The fat concentrations used were 20,40, and $60 \mathrm{~g} / 100 \mathrm{~g}$ (based on the flour content), and the remaining ingredients were added according to the ingredient balance proposed by Bennion \& Bamford (1997). For each fat concentration used, the maltogenic $\alpha$-amylase was added in the concentrations of 0,500 , and $1000 \mathrm{mg} / \mathrm{kg}$, resulting in a total of nine formulations. The formulations were identified as $\mathrm{F}_{20-0}, \mathrm{~F}_{20-500}, \mathrm{~F}_{20-1000}, \mathrm{~F}_{40-0}, \mathrm{~F}_{40-500}$, $\mathrm{F}_{40-1000}, \mathrm{~F}_{60-0}, \mathrm{~F}_{60-500}$, and $\mathrm{F}_{60-1000}$, indicating the amounts of fat and maltogenic $\alpha$-amylase added.

The cakes were made according to the flow diagram shown in Figure 1. To prepare the batters, a Hypo HB25 mixer
(Hyppolito Ltda., Ferraz de Vasconcelos, Brazil) was used, and the cakes were baked in an Ipanema IP4/80 oven (Haas Technik do Brasil Ltda., Curitiba, Brazil). After cooling, the cakes were packaged in low density polypropylene plastic bags sprayed with an anti-fungal agent. The cakes were stored in a dry place at $22 \pm 1{ }^{\circ} \mathrm{C}$.

\subsection{Evaluation of batter quality}

The $\mathrm{pH}$ value and apparent density of the batters of all the cake formulations were determined after final mixing (before putting them in the cake tins).

\section{Batter $p H$ value}

The $\mathrm{pH}$ value of the cake batters was determined using a Digimed DM-20 (Digicrom Analítica Ltda., São Paulo, SP,

Table 1. Formulations used to make the cakes.

\begin{tabular}{|c|c|c|c|c|c|c|}
\hline \multirow{4}{*}{ Ingredients } & \multicolumn{6}{|c|}{ Formulations } \\
\hline & \multicolumn{6}{|c|}{ Formulation code ${ }^{*}$} \\
\hline & \multicolumn{2}{|c|}{$\mathrm{F}_{20-0}-\mathrm{F}_{20-500}-\mathrm{F}_{20-1000}$} & \multicolumn{2}{|c|}{$\mathrm{F}_{40-0}-\mathrm{F}_{40-500}-\mathrm{F}_{40-1000}$} & \multicolumn{2}{|c|}{$\mathrm{F}_{60-0}-\mathrm{F}_{60-500}-\mathrm{F}_{60-1000}$} \\
\hline & $\%$ & grams & $\%$ & grams & $\%$ & grams \\
\hline Wheat flour ${ }^{1}$ & 95.00 & 950.00 & 95.00 & 950.00 & 95.00 & 950.00 \\
\hline Corn starch ${ }^{1}$ & 5.00 & 50.00 & 5.00 & 50.00 & 5.00 & 50.00 \\
\hline Total 1(flour basis) & 100.00 & 1000.00 & 100.00 & 1000.00 & 100.00 & 1000.00 \\
\hline Low trans fat ${ }^{2}$ & 20.00 & 200.00 & 40.00 & 400.00 & 60.00 & 600.00 \\
\hline Liquid egg ${ }^{2,4}$ & 25.00 & 250.00 & 50.00 & 500.00 & 75.00 & 750.00 \\
\hline Whole milk ${ }^{2,5}$ & 67.50 & 675.00 & 45.00 & 450.00 & 22.50 & 225.00 \\
\hline Refined sugar ${ }^{2,6}$ & 73.13 & 731.25 & 78.75 & 787.50 & 84.38 & 843.75 \\
\hline Baking powder ${ }^{2}$ & 2.50 & 25.00 & 2.50 & 25.00 & 2.50 & 25.00 \\
\hline Maltogenic $\alpha$-amylase $(\mathrm{mg} / \mathrm{kg})^{2,8}$ & \multicolumn{2}{|c|}{ Variable } & \multicolumn{2}{|c|}{ Variable } & \multicolumn{2}{|c|}{ Variable } \\
\hline Total 2 (total batter basis) & 288.13 & 2881.25 & 316.25 & 3162.50 & 344.38 & 3443.75 \\
\hline Emulsifying gel $^{3}$ & 2.00 & 57.63 & 2.00 & 63.25 & 2.00 & 68.88 \\
\hline Sodium propionate $\mathrm{e}^{3,7}$ & 0.15 & 4.32 & 0.15 & 4.74 & 0.15 & 5.17 \\
\hline Salt 3,7 & 0.20 & 5.76 & 0.20 & 6.33 & 0.20 & 6.89 \\
\hline Vanilla flavour $^{3}$ & 0.50 & 14.41 & 0.50 & 15.81 & 0.50 & 17.22 \\
\hline
\end{tabular}

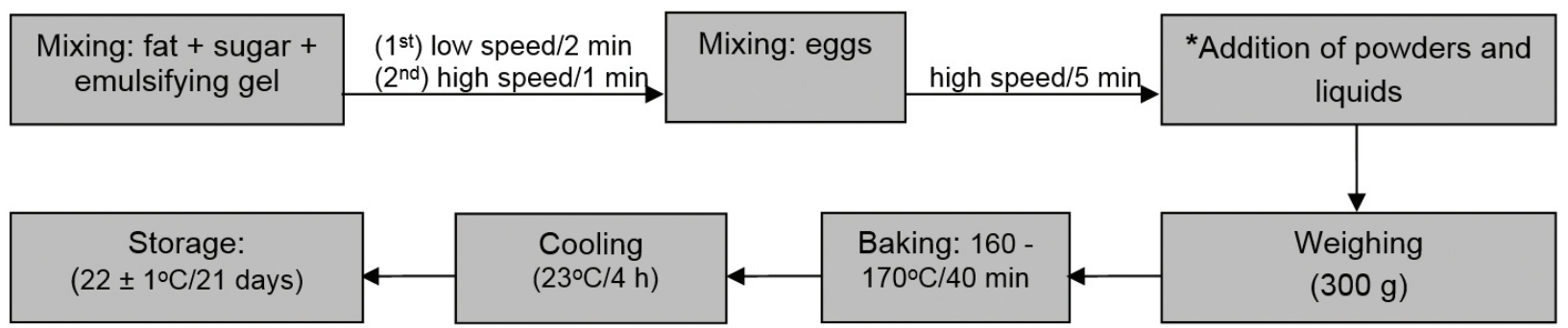

$(*)$ Previously, a mixture containing $100 \mathrm{~g}$ wheat flour and the amount of maltogenic $\alpha$-amylase corresponding to each formulation was prepared to be homegenized and incorporated to the batter. The remaining powder ingredients (flour, starch, salt, baking powder, and sodium propionate) were mixed alternating with the liquid ingredients (milk and vanilla flavor), beating at low speed for 1 minute and at high speed for 1 more minute.

Figure 1. Flow diagram of the cake-making process. 
Brazil) $\mathrm{pH}$-meter by inserting the electrode directly into a suspension of $10 \mathrm{~g}$ batter diluted in $100 \mathrm{~mL}$ distilled water.

\section{Batter density}

The density of the cake batters was determined by the relationship between the batter weight $(\mathrm{g})$ and its volume $\left(\mathrm{cm}^{3}\right)$ using a cylindrical aluminum recipient $(3.7 \mathrm{~cm}$ diameter and $6.8 \mathrm{~cm}$ height). The results were expressed in $\mathrm{g} / \mathrm{cm}^{3}$.

\subsection{Evaluation of cake quality}

Cake specific volume

The specific volume of the cakes, expressed in $\mathrm{cm}^{3} / \mathrm{g}$, was determined on the $1^{\text {st }}$ day of storage. The cake volume was determined by millet seed displacement, and the weight was measured using a semi-analytical balance. The specific volume was obtained by the ratio between the cake volume and its weight (Griswold, 1972).

\section{Crumb moisture content}

The moisture content of the cake crumbs was determined on the $1^{\text {st }}, 7^{\text {th }}, 14^{\text {th }}$, and $21^{\text {st }}$ days of storage, according to AACC method no 44-15A (AMERICAN ASSOCIATION OF CEREAL CHEMISTS, 2000).

\section{Crumb instrumental texture}

Texture was analyzed using the TAXT2i (Texture Technologies Corp., Scarsdale, NY, USA/Stable Micro Systems, Godalming, Surrey, UK) texture analyzer, according to AACC method no 74-09 (AMERICAN ASSOCIATION OF CEREAL CHEMISTS, 2000). Two central slices, $1.25 \mathrm{~cm}$ thick each, placed one on top of the other, were compressed to $40 \%$ of their original height using a cylindrical aluminum probe of $36 \mathrm{~mm}$ diameter (P 36/R) and the following operational parameters: $1.0 \mathrm{~m} / \mathrm{s}$ pre-test speed; $1.7 \mathrm{~m} / \mathrm{s}$ test speed, $10.0 \mathrm{~m} / \mathrm{s}$ post-test speed; $5 \mathrm{~g}$ force; and $5 \mathrm{~s}$ counting cycle, measuring the compression force. The samples were kept in their original packaging and removed one by one before the analysis to avoid staling if exposed to the environment, which could interfere with the texture results due to the sensitivity of the equipment. The analysis was carried out in sextuplicate, and the parameter measured was firmness; the results were expressed in gf.

\section{Sensory analysis: evaluation of acceptance and purchase intention}

Based on the results obtained in the evaluation of the cakes during 21 days of storage, a sensory analysis and determination of purchase intention was carried out for the 3 formulations with $20 \mathrm{~g} / 100 \mathrm{~g}$ fat and the 3 levels of maltogenic $\alpha$-amylase $(0,500$ and $1000 \mathrm{mg} / \mathrm{kg}$ ). The analyses were carried out with 50 non-trained judges, potential cake consumers. The following parameters were evaluated in the acceptance analysis: appearance, aroma, taste, texture, and overall acceptance, using a 9-point hedonic scale $(1=$ disliked immensely; $9=$ liked immensely). The results were expressed as the mean of the scores. A 5-point scale was used for purchase intention $(1=$ would certainly not buy; $5=$ would certainly buy). The results were expressed as the percentage of judges who attributed different scores. The sensory analysis was carried out 7 days after manufacture to identify any effects caused by storage considering a shelf life of 21 days. This research project was approved by the University of Campinas Research Ethics Committee, process number 0221.0.146.000-10, in accordance with Resolution 196/96 of the Brazilian Health Council.

\subsection{Analysis of the results}

The statistical analysis of the results was carried out using the SAS 9.2 software (SAS Institute, Cary, NC, USA) and the Tukey's test at $5 \%$ probability level.

\section{Results and discussion}

\subsection{Batter $\mathrm{pH}$ and density}

Table 2 shows the $\mathrm{pH}$ and density results of the batters. With respect to $\mathrm{pH}$, the values found varied between 7.24 and 7.61, corresponding to samples $\mathrm{F}_{20-1000}$ and $\mathrm{F}_{40-500}$, respectively. These $\mathrm{pH}$ values are appropriate for cake making. According to Ash \& Colmey (1973) (apud Khalil, 1998), pH values in the range from 6.50 to 7.70 are considered ideal for cake processing. According to Pyler (1973), $\mathrm{pH}$ is of great importance in the definition of color and texture of cakes. Texture tends to become softer as the $\mathrm{pH}$ increases, but a very high $\mathrm{pH}$ value is undesirable because it produces an undesirable alkaline taste. The density value of $20 \mathrm{~g} / 100 \mathrm{~g}$ fat batters was significantly higher $(\mathrm{p}<0.05)$ than that of the 40 and $60 \mathrm{~g} / 100 \mathrm{~g}$ fat batters. Lower values of density indicate the incorporation of a greater amount of air into the batter (Kocer et al., 2007). The addition of maltogenic $\alpha$-amylase had no influence on density.

\subsection{Cake specific volume}

Table 2 shows the results of the specific volume of the cakes. Comparing the specific volumes of cakes made without the addition of maltogenic $\alpha$-amylase $(p<0.05)$, it can be

Table 2. Density and $\mathrm{pH}$ of the batters and specific volume of the cakes made with different amounts of fat and maltogenic $\alpha$-amylase.

\begin{tabular}{|c|c|c|c|}
\hline Formulation & $\mathrm{pH}^{*}$ & Density $\left(\mathrm{g} / \mathrm{cm}^{3}\right)^{*}$ & $\begin{array}{c}\text { Specific volume } \\
\left(\mathrm{cm}^{3} / \mathrm{g}\right)^{*}\end{array}$ \\
\hline $\mathrm{F}_{20-0}$ & $7.49 \pm 0.04^{a b}$ & $0.90 \pm 0.01^{a}$ & $2.37 \pm 0.07^{\mathrm{cd}}$ \\
\hline $\mathrm{F}_{20-500}$ & $7.31 \pm 0.09^{b c}$ & $0.88 \pm 0.02^{a}$ & $2.38 \pm 0.02^{\mathrm{cd}}$ \\
\hline $\mathrm{F}_{20-1000}$ & $7.24 \pm 0.07^{\mathrm{c}}$ & $0.88 \pm 0.01^{\mathrm{a}}$ & $2.87 \pm 0.13^{a}$ \\
\hline $\mathrm{F}_{40-0}$ & $7.50 \pm 0.08^{a b}$ & $0.82 \pm 0.01^{b}$ & $2.75 \pm 0.06^{\mathrm{ab}}$ \\
\hline $\mathrm{F}_{40-500}$ & $7.61 \pm 0.03^{a}$ & $0.81 \pm 0.00^{b c}$ & $2.45 \pm 0.04^{\mathrm{cd}}$ \\
\hline $\mathrm{F}_{40-1000}$ & $7.45 \pm 0.11^{a b}$ & $0.81 \pm 0.01 \mathrm{bc}$ & $2.49 \pm 0.02^{\mathrm{cd}}$ \\
\hline $\mathrm{F}_{60-0}$ & $7.40 \pm 0.05^{b c}$ & $0.79 \pm 0.01^{\mathrm{cd}}$ & $2.33 \pm 0.03^{d}$ \\
\hline $\mathrm{F}_{60-500}$ & $7.43 \pm 0.04^{a b c}$ & $0.79 \pm 0.00^{\mathrm{bcd}}$ & $2.76 \pm 0.13^{a b}$ \\
\hline $\mathrm{F}_{60-1000}$ & $7.49 \pm 0.09^{a b}$ & $0.77 \pm 0.01^{\mathrm{d}}$ & $2.56 \pm 0.01^{b c}$ \\
\hline \multicolumn{4}{|c|}{$\begin{array}{l}\mathrm{F}_{20-0}: 20 \mathrm{~g} / 100 \mathrm{~g} \text { fat and } 0 \mathrm{mg} / \mathrm{kg} \text { maltogenic } \alpha \text {-amylase; } \mathrm{F}_{20-500}: 20 \mathrm{~g} / 100 \mathrm{~g} \text { fat and } 500 \mathrm{mg} / \mathrm{kg} \\
\text { maltogenic } \alpha \text {-amylase; } \mathrm{F}_{20-1000}: 20 \mathrm{~g} / 100 \mathrm{~g} \text { fat and } 1000 \mathrm{mg} / \mathrm{kg} \text { maltogenic } \alpha \text {-amylase; } \mathrm{F}_{40-0-0}: \\
40 \mathrm{~g} / 100 \mathrm{~g} \text { fat and } 0 \mathrm{mg} / \mathrm{kg} \text { maltogenic } \alpha \text {-amylase; } \mathrm{F}_{40-500}: 40 \mathrm{~g} / 100 \mathrm{~g} \text { fat and } 500 \mathrm{mg} / \\
\mathrm{kg} \text { maltogenic } \alpha \text {-amylase; } \mathrm{F}_{40-1000}: 40 \mathrm{~g} / 100 \mathrm{~g} \text { fat and } 1000 \mathrm{mg} / \mathrm{kg} \text { maltogenic } \alpha \text {-amylase; } \\
\mathrm{F}_{60-0}: 60 \mathrm{~g} / 100 \mathrm{~g} \text { fat and } 0 \mathrm{mg} / \mathrm{kg} \text { maltogenic } \alpha \text {-amylase; } \mathrm{F}_{60-500}: 60 \mathrm{~g} / 100 \mathrm{~g} \text { fat and } 500 \mathrm{mg} / \\
\mathrm{kg} \text { maltogenic } \alpha \text {-amylase; } \mathrm{F}_{60-1000}: 60 \mathrm{~g} / 100 \mathrm{~g} \text { fat and } 1000 \mathrm{mg} / \mathrm{kg} \text { maltogenic } \alpha \text {-amylase. } \\
(*) \text { The values of } \mathrm{pH} \text {, apparent density and specific volume are the means of triplicates. } \\
\text { Means with the same letter in the same column do not differ statistically according to } \\
\text { Tukey's test }(\mathrm{p}<0.05 \text { ). }\end{array}$} \\
\hline
\end{tabular}


seen that the highest value was obtained with the $40 \mathrm{~g} / 100 \mathrm{~g}$ fat formulation, $2.75 \mathrm{~cm}^{3} / \mathrm{g}$. A similar result was reported by Sakiyan et al. (2004), who studied the effect of the addition of different fat concentrations (from 0 to $50 \%$ ) and two types of emulsifiers (at 3\% dosage) in the production of cakes, demonstrating that specific volume increased with the increase of fat in the formulation. It is known that the main role of fat in cakes is to incorporate air in the batter allowing gas cells to expand during the baking phase enabling the cake to rise uniformly with an adequate volume of the final product (Hoseney, 1998; Ghotra et al., 2002; Sakiyan et al., 2004; Kocer et al., 2007). However, an excess of fat can weaken the structure and lead to collapse (Bennion \& Bamford, 1997).

When the enzyme was added at a concentration of $500 \mathrm{mg} / \mathrm{kg}$, the highest value of specific volume obtained was $2.76 \mathrm{~cm}^{3} / \mathrm{g}$ corresponding to the cakes formulated with $60 \mathrm{~g} / 100 \mathrm{~g}$, but when the enzyme was added at a concentration of $1000 \mathrm{mg} / \mathrm{kg}$, the highest value obtained was $2.87 \mathrm{~cm}^{3} / \mathrm{g}$, corresponding to the cakes formulated with $20 \mathrm{~g} / 100 \mathrm{~g}$ fat. This could indicate that it is possible to make cakes with lower fat contents and quality similar to that of cakes with the higher fat contents using the enzyme maltogenic $\alpha$-amylase. When a cake batter is placed in the oven, continuous heating promotes starch gelatinization (Kocer et al., 2007; Sablani, 2009) and, the higher the gelatinization temperature, the more time available for the cake to rise before the structure sets (Gaonkar \& Mcpherson, 2006). Accordingly, delayed gelatinization can occur with the presence of lipids (Ghiasi et al., 1982), sugars, and proteins (Şumnu et al., 1999). Furthermore, maltogenic $\alpha$-amylase reduces batter viscosity during starch gelatinization, prolonging oven rise and resulting in cakes with higher volumes (Mathewson, 2000; Goesaert et al., 2009b); this is a characteristic of high quality cakes (Esteller \& Lannes, 2005).

\subsection{Crumb moisture content}

Table 3 shows the results of the analysis of the moisture content of the cake crumbs during 21 days of storage. It can be seen that on each day of analysis, the cakes with $20 \mathrm{~g} / 100 \mathrm{~g}$ fat were significantly moister $(\mathrm{p}<0.05)$, followed by those formulated with 40 and $60 \mathrm{~g} / 100 \mathrm{~g}$ fat, respectively. This behavior can be explained by the fact that when determining the best formulation according to the ingredient balance rules, the amount of sugar increased with the increase in the fat concentration, thus increasing the total solids content.

Of all cakes made with $20 \mathrm{~g} / 100 \mathrm{~g}$ fat, those made with $1000 \mathrm{mg} / \mathrm{kg}$ maltogenic $\alpha$-amylase lost the least amount of moisture during storage $(12 \mathrm{~g} / 100 \mathrm{~g})$, decreasing from $28.90 \mathrm{~g} / 100 \mathrm{~g}$ (day 1 ) to $25.53 \mathrm{~g} / 100 \mathrm{~g}$ (day 21). This could have been a consequence of the enzymatic hydrolysis of the starch due to the action of the maltogenic $\alpha$-amylase with the formation of hygroscopic dextrins, as explained by Van der Maarel et al. (2002). This amount of moisture loss was low compared to that of the other samples, such as $\mathrm{F}_{40-500}$ and $\mathrm{F}_{40-1000}$, in which moisture loss was about 20 and $24 \mathrm{~g} / 100 \mathrm{~g}$, respectively, in the same period.

\subsection{Crumb instrumental texture}

Table 4 shows the behavior of the cakes according to enzyme concentration with respect to crumb firmness during the 21 days of storage. It can be seen that the firmness of the nine formulations of cake increased during storage. According to Fadda et al. (2014), after baking, bakery products undergo various chemical and physical changes that are related to staling, but this phenomenon is a complex process that has not yet been fully understood. The most important factors responsible for these changes are starch transformation, starch-gluten interactions, and moisture redistribution. On the $1^{\text {st }}$ day of storage, the values of firmness varied between $637.35 \mathrm{gf}$ (sample $\mathrm{F}_{20-1000}$ ) and $1684.19 \mathrm{gf}\left(\right.$ sample $\left.\mathrm{F}_{60-0}\right)$, and on the $21^{\text {st }}$ day, between $988.47 \mathrm{gf}\left(\right.$ sample $\left.\mathrm{F}_{20-1000}\right)$ and $1940.59 \mathrm{gf}\left(\right.$ sample $\left.\mathrm{F}_{60-0}\right)$, showing that both fat and the maltogenic $\alpha$-amylase contents had an influence on cake texture. The addition of the enzyme had a positive effect on the cakes, softening the crumb and avoiding an increase in firmness during storage. The effect of the fat content can be observed when comparing samples without the enzyme maltogenic $\alpha$-amylase. Cakes with $40 \mathrm{~g} / 100 \mathrm{~g}$ fat were the softest

Table 3. Moisture contents of the cake crumbs with different amounts of fat and maltogenic $\alpha$-amylase during 21 days of storage.

\begin{tabular}{|c|c|c|c|c|}
\hline \multirow{3}{*}{ Formulation } & \multicolumn{4}{|c|}{ Moisture content ${ }^{*}$} \\
\hline & \multicolumn{4}{|c|}{ Days of storage } \\
\hline & $1^{\text {st }}$ day & $7^{\text {th }}$ day & $14^{\text {th }}$ day & $21^{\text {st }}$ day \\
\hline $\mathrm{F}_{20-0}$ & $29.63 \pm 0.56^{\mathrm{a}, \mathrm{AB}}$ & $28.42 \pm 0.15^{\mathrm{b}, \mathrm{A}}$ & $26.94 \pm 0.57^{c, A}$ & $25.37 \pm 0.10^{\mathrm{d}, \mathrm{A}}$ \\
\hline $\mathrm{F}_{20-500}$ & $30.14 \pm 0.09^{\mathrm{a}, \mathrm{A}}$ & $27.27 \pm 0.35^{\mathrm{b}, \mathrm{B}}$ & $26.87 \pm 0.31^{\mathrm{b}, \mathrm{A}}$ & $25.38 \pm 0.24^{\mathrm{c}, \mathrm{A}}$ \\
\hline $\mathrm{F}_{20-1000}$ & $28.90 \pm 0.34^{\mathrm{a}, \mathrm{AB}}$ & $27.47 \pm 0.38^{\mathrm{b}, \mathrm{AB}}$ & $27.52 \pm 0.23^{\mathrm{b}, \mathrm{A}}$ & $25.53 \pm 0.12^{c, A}$ \\
\hline $\mathrm{F}_{40-0}$ & $27.38 \pm 0.67^{\mathrm{a}, \mathrm{CD}}$ & $24.79 \pm 0.21^{\mathrm{b}, \mathrm{C}}$ & $23.52 \pm 0.15^{\mathrm{bc}, \mathrm{B}}$ & $22.67 \pm 0.35^{\mathrm{c}, \mathrm{B}}$ \\
\hline $\mathrm{F}_{40-500}$ & $28.31 \pm 0.55^{\mathrm{a}, \mathrm{BC}}$ & $24.60 \pm 0.45^{\mathrm{b}, \mathrm{C}}$ & $24.21 \pm 0.37^{\mathrm{b}, \mathrm{B}}$ & $21.51 \pm 0.36^{\mathrm{c}, \mathrm{C}}$ \\
\hline $\mathrm{F}_{40-1000}$ & $26.79 \pm 0.22^{\mathrm{a}, \mathrm{D}}$ & $24.29 \pm 0.21^{\mathrm{b}, \mathrm{C}}$ & $23.77 \pm 0.49^{\mathrm{b}, \mathrm{B}}$ & $21.38 \pm 0.25^{\mathrm{c}, \mathrm{CD}}$ \\
\hline $\mathrm{F}_{60-0}$ & $24.32 \pm 0.49^{\mathrm{a}, \mathrm{E}}$ & $21.37 \pm 0.53^{\mathrm{b}, \mathrm{D}}$ & $21.13 \pm 0.01^{\mathrm{b}, \mathrm{C}}$ & $20.56 \pm 0.29^{b, C D}$ \\
\hline $\mathrm{F}_{60-500}$ & $24.95 \pm 0.38^{\mathrm{a}, \mathrm{E}}$ & $22.29 \pm 0.52^{\mathrm{b}, \mathrm{D}}$ & $21.26 \pm 0.41^{b c, c}$ & $20.64 \pm 0.48^{\mathrm{c}, \mathrm{D}}$ \\
\hline $\mathrm{F}_{60-1000}$ & $23.42 \pm 0.60^{\mathrm{a}, \mathrm{F}}$ & $21.76 \pm 0.32^{\mathrm{b}, \mathrm{D}}$ & $21.51 \pm 0.33^{\mathrm{b}, \mathrm{C}}$ & $19.50 \pm 0.47^{\mathrm{c}, \mathrm{E}}$ \\
\hline
\end{tabular}

$\mathrm{F}_{20-0}: 20 \mathrm{~g} / 100 \mathrm{~g}$ fat and $0 \mathrm{mg} / \mathrm{kg}$ maltogenic $\alpha$-amylase; $\mathrm{F}_{20-500}: 20 \mathrm{~g} / 100 \mathrm{~g}$ fat and $500 \mathrm{mg} / \mathrm{kg}$ maltogenic $\alpha$-amylase; $\mathrm{F}_{20-1000}: 20 \mathrm{~g} / 100 \mathrm{~g}$ fat and $1000 \mathrm{mg} / \mathrm{kg}$ maltogenic $\alpha$-amylase; $\mathrm{F}_{40-0}:$ $40 \mathrm{~g} / 100 \mathrm{~g}$ fat and $0 \mathrm{mg} / \mathrm{kg}$ maltogenic $\alpha$-amylase; $\mathrm{F}_{40-500}: 40 \mathrm{~g} / 100 \mathrm{~g}$ fat and $500 \mathrm{mg} / \mathrm{kg}$ maltogenic $\alpha$-amylase; $\mathrm{F}_{40-1000}: 40 \mathrm{~g} / 100 \mathrm{~g}$ fat and $1000 \mathrm{mg} / \mathrm{kg}$ maltogenic $\alpha$-amylase; $\mathrm{F}_{60-0}:$ $60 \mathrm{~g} / 100 \mathrm{~g}$ fat and $0 \mathrm{mg} / \mathrm{kg}$ maltogenic $\alpha$-amylase; $\mathrm{F}_{60-500}: 60 \mathrm{~g} / 100 \mathrm{~g}$ fat and $500 \mathrm{mg} / \mathrm{kg}$ maltogenic $\alpha$-amylase; $\mathrm{F}_{60-1000}: 60 \mathrm{~g} / 100 \mathrm{~g}$ fat and $1000 \mathrm{mg} / \mathrm{kg}$ maltogenic $\alpha$-amylase. ${ }^{(*)} \mathrm{The}$ values of moisture content represent the means of triplicates. Means with the same small letter in the same line, or capital letter in the same column, do not differ statistically according to Tukey's test $(\mathrm{p}<0.05)$. 
throughout the whole storage period. The addition of the enzyme maltogenic $\alpha$-amylase, especially at the concentration of $1000 \mathrm{mg} / \mathrm{kg}$, resulted in cakes with reduced firmness on all the days of analysis, minimizing the effect of the fat content. Thus, one can obtain cakes with lower fat contents $(20 \mathrm{~g} / 100 \mathrm{~g})$ with firmness similar to that of cakes with $40 \mathrm{~g} / 100 \mathrm{~g}$ fat, which could be beneficial from the nutritional point of view.

As explained by Goesaert et al. (2009b), the anti-firmness mechanism of maltogenic $\alpha$-amylase is fundamentally attributed to the extensive degradation of the crystallizable fraction of amylopectin, inhibiting the formation of a stable amylopectin network during storage, thus inhibiting retrogradation. It can therefore be said that in cakes made with a smaller amount of fat $(20 \mathrm{~g} / 100 \mathrm{~g})$, the effect of maltogenic $\alpha$-amylase was more apparent, but as the amount of fat increased, there was a combined effect of the fat and the enzyme retarding the increase in firmness.

\subsection{Sensory analysis: evaluation of acceptance and purchase intention}

Table 5 shows the results of the acceptance test for cakes with $20 \mathrm{~g} / 100 \mathrm{~g}$ fat and the addition of 0,500 , and $1000 \mathrm{mg} / \mathrm{kg}$ maltogenic $\alpha$-amylase. Figure 2 shows pictures of a slice of each of these cakes. The results of the acceptance of the attributes of aroma and taste indicated that there was no significant difference $(p<0.05)$ between the samples evaluated by the consumers, and although no difference was found for overall impression, the sample with $20 \mathrm{~g} / 100 \mathrm{~g}$ fat and $1000 \mathrm{mg} / \mathrm{kg}$ maltogenic $a$-amylase (sample $\mathrm{F}_{20-1000}$ ) stood out in a positive way, in terms of appearance.

Table 4. Comparison of the behavior of crumb firmness of the cakes with (a) 0, (b) 500, and (c) $1000 \mathrm{mg} / \mathrm{kg}$ of maltogenic $\alpha$-amylase in the formulations with 20,40 , and $60 \mathrm{~g} / 100 \mathrm{~g}$ fat, during 21 days of storage.

\begin{tabular}{|c|c|c|c|c|}
\hline \multirow{3}{*}{ Formulation } & \multicolumn{4}{|c|}{ Firmness (gf) } \\
\hline & \multicolumn{4}{|c|}{ Days of storage } \\
\hline & $1^{\text {st }}$ day & $7^{\text {th }}$ day & $14^{\text {th }}$ day & $21^{\text {st }}$ day \\
\hline $\mathrm{F}_{20-0}$ & $1293.14 \pm 93.05^{\mathrm{c}, \mathrm{B}}$ & $1389.65 \pm 58.56^{\mathrm{bc}, \mathrm{B}}$ & $1469.73 \pm 58.08^{\mathrm{b}, \mathrm{A}}$ & $1741.32 \pm 77.25^{\mathrm{a}, \mathrm{B}}$ \\
\hline $\mathrm{F}_{20-500}$ & $792.82 \pm 64.30^{\mathrm{d}, \mathrm{E}}$ & $921.59 \pm 37.64^{\mathrm{c}, \mathrm{E}}$ & $1249.64 \pm 83.43^{\mathrm{b}, \mathrm{B}}$ & $1483.74 \pm 66.27^{\mathrm{a}, \mathrm{C}}$ \\
\hline $\mathrm{F}_{20-1000}$ & $637.35 \pm 53.24^{\mathrm{b}, \mathrm{F}}$ & $907.15 \pm 17.58^{\mathrm{a}, \mathrm{E}}$ & $930.82 \pm 34.18^{\mathrm{a}, \mathrm{D}}$ & $988.47 \pm 85.45^{\mathrm{a}, \mathrm{E}}$ \\
\hline $\mathrm{F}_{40-0}$ & $1037.75 \pm 60.39^{\mathrm{b}, \mathrm{C}}$ & $1196.69 \pm 52.37^{\mathrm{ab}, \mathrm{CD}}$ & $1136.76 \pm 78.9^{\mathrm{b}, \mathrm{BC}}$ & $1345.74 \pm 60.69^{\mathrm{a}, \mathrm{CD}}$ \\
\hline $\mathrm{F}_{40-500}$ & $956.46 \pm 63.0^{\mathrm{b}, \mathrm{CD}}$ & $959.14 \pm 40.48^{\mathrm{ab}, \mathrm{E}}$ & $1091.69 \pm 83.16^{\mathrm{a}, \mathrm{BCD}}$ & $1038.42 \pm 93.52^{a b, E}$ \\
\hline $\mathrm{F}_{40-1000}$ & $866.08 \pm 59.22$ b,DE & $925.60 \pm 56.78^{\mathrm{b}, \mathrm{E}}$ & $1177.74 \pm 53.53^{\mathrm{a}, \mathrm{BC}}$ & $1111.17 \pm 94.44^{\mathrm{a}, \mathrm{E}}$ \\
\hline $\mathrm{F}_{60-0}$ & $1684.19 \pm 110.14^{\mathrm{b}, \mathrm{A}}$ & $1546.34 \pm 26.33^{\mathrm{b}, \mathrm{A}}$ & $1606.05 \pm 153.01^{\mathrm{b}, \mathrm{A}}$ & $1940.59 \pm 91.24^{\mathrm{a}, \mathrm{A}}$ \\
\hline $\mathrm{F}_{60-500}$ & $1063.41 \pm 46.85^{\mathrm{b}, \mathrm{C}}$ & $1294.12 \pm 78.08^{\mathrm{a}, \mathrm{BC}}$ & $1226.04 \pm 33.73^{\mathrm{a}, \mathrm{B}}$ & $1315.64 \pm 103.50^{\mathrm{a}, \mathrm{CD}}$ \\
\hline $\mathrm{F}_{60-1000}$ & $918.97 \pm 61.54^{c, \mathrm{CDE}}$ & $1094.41 \pm 65.84^{\mathrm{ab}, \mathrm{D}}$ & $1025.14 \pm 33.26^{\mathrm{bc}, \mathrm{CD}}$ & $1157.59 \pm 86.23^{\mathrm{a}, \mathrm{DE}}$ \\
\hline
\end{tabular}

$\mathrm{F}_{20-0}: 20 \mathrm{~g} / 100 \mathrm{~g}$ fat and $0 \mathrm{mg} / \mathrm{kg}$ maltogenic $\alpha$-amylase; $\mathrm{F}_{20-500}: 20 \mathrm{~g} / 100 \mathrm{~g}$ fat and $500 \mathrm{mg} / \mathrm{kg}$ maltogenic $\alpha$-amylase; $\mathrm{F}_{20-1000}: 20 \mathrm{~g} / 100 \mathrm{~g}$ fat and $1000 \mathrm{mg} / \mathrm{kg}$ maltogenic $\alpha$-amylase; $\mathrm{F}_{40-0}$ : $40 \mathrm{~g} / 100 \mathrm{~g}$ fat and $0 \mathrm{mg} / \mathrm{kg}$ maltogenic $\alpha$-amylase; $\mathrm{F}_{40-500}: 40 \mathrm{~g} / 100 \mathrm{~g}$ fat and $500 \mathrm{mg} / \mathrm{kg}$ maltogenic $\alpha$-amylase; $\mathrm{F}_{40-1000}: 40 \mathrm{~g} / 100 \mathrm{~g}$ fat and $1000 \mathrm{mg} / \mathrm{kg}$ maltogenic $\alpha$-amylase; $\mathrm{F}_{60-0}: 60 \mathrm{~g} / 100 \mathrm{~g}$ fat and $0 \mathrm{mg} / \mathrm{kg}$ maltogenic $\alpha$-amylase; $\mathrm{F}_{60-500}: 60 \mathrm{~g} / 100 \mathrm{~g}$ fat and $500 \mathrm{mg} / \mathrm{kg}$ maltogenic $\alpha$-amylase; $\mathrm{F}_{60-1000}: 60 \mathrm{~g} / 100 \mathrm{~g}$ fat and $1000 \mathrm{mg} / \mathrm{kg}$ maltogenic $\alpha$-amylase. ${ }^{(*)}$ The values of firmness represent the means of six replicates. Means with the same small letter in the same line, or capital letter in the same column, do not differ statistically according to Tukey's test ( $\mathrm{p}<0.05)$.

Table 5. Mean acceptance scores of the sensory attributes of cakes with $20 \mathrm{~g} / 100 \mathrm{~g}$ fat and the addition of 0 , 500, and $1000 \mathrm{mg} / \mathrm{kg}$ maltogenic a-amylase.

\begin{tabular}{cccccc}
\hline \multirow{2}{*}{ Sample } & \multicolumn{4}{c}{ Attribute $^{*}$} \\
\cline { 2 - 6 } & Appearance & Aroma & Taste & Texture & Overall Impression \\
\hline $\mathbf{F}_{20-0}$ & $6.58 \pm 1.68^{\mathrm{b}}$ & $7.26 \pm 1.23^{\mathrm{a}}$ & $7.12 \pm 1.22^{\mathrm{a}}$ & $6.66 \pm 1.52^{\mathrm{b}}$ & $7.00 \pm 1.29^{\mathrm{a}}$ \\
$\mathbf{F}_{20-500}$ & $6.52 \pm 1.83^{\mathrm{b}}$ & $7.54 \pm 1.11^{\mathrm{a}}$ & $7.12 \pm 1.31^{\mathrm{a}}$ & $7.34 \pm 1.14^{\mathrm{a}}$ & $7.10 \pm 1.30^{\mathrm{a}}$ \\
$\mathbf{F}_{20-1000}$ & $7.54 \pm 1.26^{\mathrm{a}}$ & $7.36 \pm 1.29^{\mathrm{a}}$ & $7.22 \pm 1.27^{\mathrm{a}}$ & $7.50 \pm 1.20^{\mathrm{a}}$ & $7.38 \pm 1.12^{\mathrm{a}}$ \\
\hline
\end{tabular}

$\mathrm{F}_{20-0}: 20 \mathrm{~g} / 100 \mathrm{~g}$ fat and $0 \mathrm{mg} / \mathrm{kg}$ maltogenic $\alpha$-amylase; $\mathrm{F}_{20-500}: 20 \mathrm{~g} / 100 \mathrm{~g}$ fat and $500 \mathrm{mg} / \mathrm{kg}$ maltogenic $\alpha$-amylase; $\mathrm{F}_{20-1000}: 20 \mathrm{~g} / 100 \mathrm{~g}$ fat and $1000 \mathrm{mg} / \mathrm{kg}$ maltogenic $\alpha$-amylase. ${ }^{(*)} \mathrm{Means}$ followed by the same letters in the same column do not differ statistically according to Tukey's test $(\mathrm{p}<0.05)$.
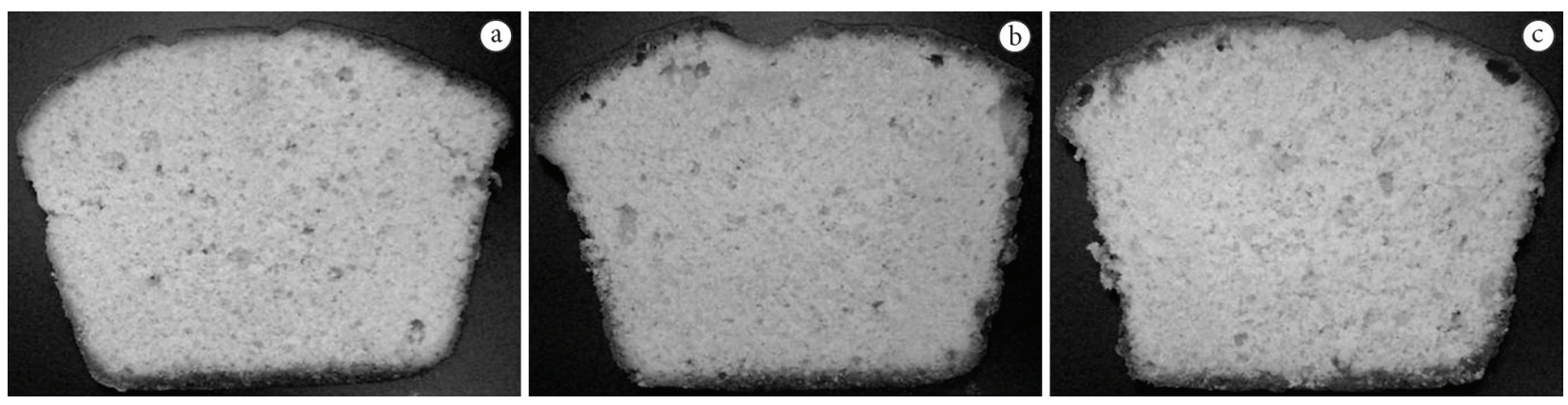

Figure 2. Slices of the cakes with $20 \mathrm{~g} / 100 \mathrm{~g}$ fat and (a) 0, (b) 500, and (c) $1000 \mathrm{mg} / \mathrm{kg}$ maltogenic $\alpha$-amylase. 


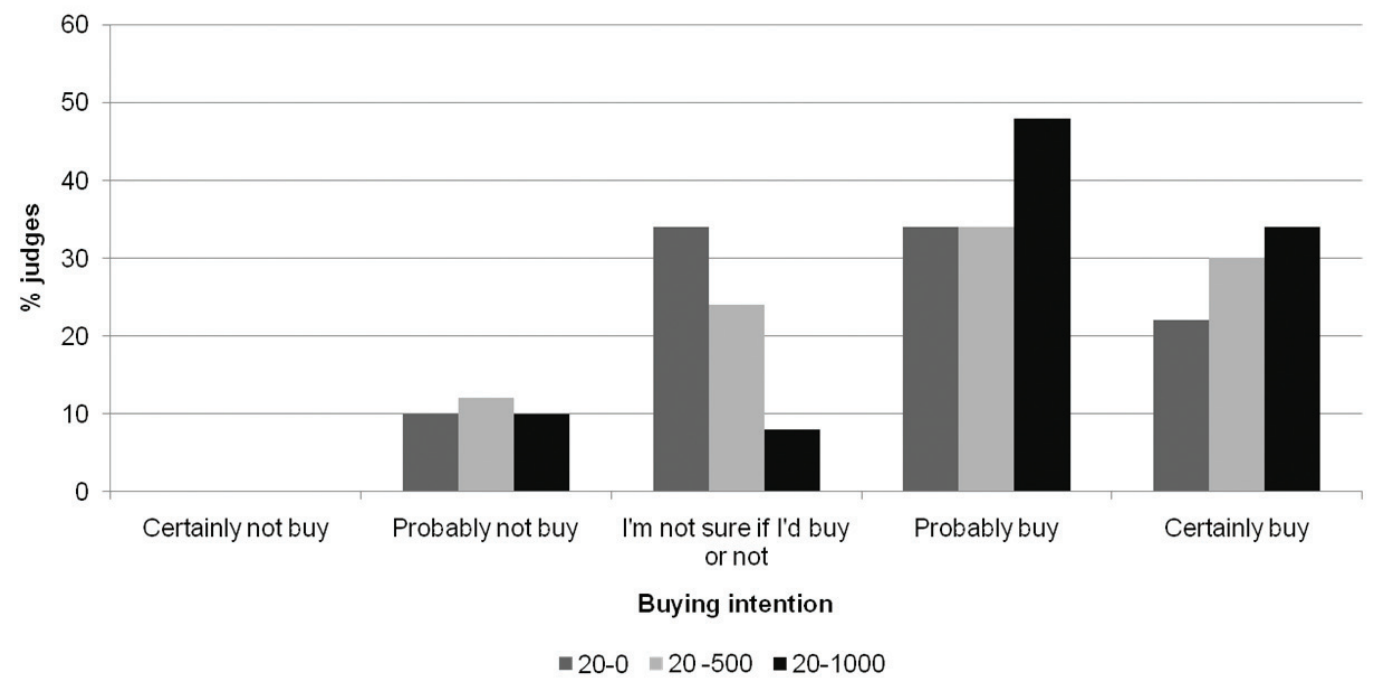

Figure 3. Purchase intention of the cakes with $20 \mathrm{~g} / 100 \mathrm{~g}$ fat with the three levels of maltogenic $\alpha$-amylase $(0,500 \mathrm{and} 1000 \mathrm{mg} / \mathrm{kg}) . \mathrm{F}_{20-0}$ : $20 \mathrm{~g} / 100 \mathrm{~g}$ fat and $0 \mathrm{mg} / \mathrm{kg}$ maltogenic $\alpha$-amylase; $\mathrm{F}_{20-500}: 20 \mathrm{~g} / 100 \mathrm{~g}$ fat and $500 \mathrm{mg} / \mathrm{kg}$ maltogenic $\alpha$-amylase; $\mathrm{F}_{20-1000}: 20 \mathrm{~g} / 100 \mathrm{~g}$ fat and $1000 \mathrm{mg} / \mathrm{kg}$ maltogenic a-amylase.

This fact represents a positive outcome and is related to the cake quality results obtained, in which this same sample had a higher specific volume than that of the cakes with $20 \mathrm{~g} / 100 \mathrm{~g}$ fat and 0 or $500 \mathrm{mg} / \mathrm{kg}$ of enzyme. With respect to the acceptance of the attribute texture, the sample with no enzyme received a lower score than the other two samples, confirming the results for texture obtained instrumentally (Table 4), which showed that the addition of maltogenic $\alpha$-amylase produced a softer product.

Figure 3 shows the purchase intention of the judges with respect to the samples evaluated.

Purchase intention was greater for the samples with maltogenic $\alpha$-amylase, and the sample $\mathrm{F}_{20-1000}$ stood out. Correlating these results with the scores obtained in the acceptance test, the samples with 500 and $1000 \mathrm{mg} / \mathrm{kg}$ of enzyme showed the same characteristics of aroma, taste, texture, and overall impression. However, the cake with $1000 \mathrm{mg} / \mathrm{kg}$ maltogenic $\alpha$-amylase showed the highest score for the attribute appearance, which influenced consumer purchase intention.

\section{Conclusions}

High concentrations of fat in the cake formulations, independent of the addition of the enzyme maltogenic $\alpha$-amylase, led to a product with less desirable quality.

The effect of the maltogenic $\alpha$-amylase was evident on the results of specific volume, texture, and sensory evaluation of the cakes.

The fat and maltogenic $\alpha$-amylase combinations that best maintained the softness of the cake during 21 days of storage correspond to the formulations with a fat to maltogenic a-amylase ratio (in $\mathrm{g} / 100 \mathrm{~g}$ to $\mathrm{mg} / \mathrm{kg}$ ) of $20 / 1000,40 / 500$, and $40 / 1000$

In general, the formulation with $20 \mathrm{~g} / 100 \mathrm{~g}$ fat and $1000 \mathrm{mg} / \mathrm{kg}$ maltogenic $\alpha$-amylase (flour basis) was the one that showed the best results (greater specific volume, lower moisture loss, better texture, better sensory evaluation), representing a beneficial alternative from the nutritional point of view since the addition of the enzyme provided quality improvements maintaining the fat level at $20 \mathrm{~g} / 100 \mathrm{~g}$.

\section{References}

American Association Of Cereal Chemists - AACC. 2000. Approved methods of analysis. 10th ed. St. Paul: AACC.

Bennion, E. B., \& Bamford, G. S. T. (1997). The technology of cake making. 6th ed. London: Blackie Academic and Professional. 421 p. http://dx.doi.org/10.1007/978-1-4757-6690-5.

Esteller, M. S., Yoshimoto, R. M. O., Amaral, R. L., \& Lannes, S. C. S. (2004). Uso de açúcares em produtos panificados. Ciência e Tecnologia de Alimentos, 24(4), 602-607. http://dx.doi.org/10.1590/ S0101-20612004000400021.

Esteller, M. S., \& Lannes, S. C. S. (2005). Parâmetros complementares para fixação de identidade e qualidade de produtos panificados. Ciência e Tecnologia de Alimentos, 25(4), 802-806. http://dx.doi. org/10.1590/S0101-20612005000400028.

Fadda, C., Sanguinetti, A. M., Del Caro, A., Collar, C., \& Piga, A. (2014). Bread Staling: Updating the View. Comprehensive Reviews in Food Science and Food Safety, 13(4), 473-492. http://dx.doi. org/10.1111/1541-4337.12064.

Gaonkar, A. G., \& Mcpherson, A. (2006). Ingredient interactions: effects on food quality. In J. J. Mitolo (Ed.), Starch selection and interaction in foods (pp. 140-164). Boca Raton: CRC Press.

Ghiasi, K., et al (1982). Gelatinization of wheat starch. I. Excess-water systems. Cereal Chemistry, 59(4), 81-85.

Ghotra, B. S., Dyal, S. D., \& Narine, S. S. (2002). Lipid shortenings: a review. Food Research International, 35(10), 1015-1048. http:// dx.doi.org/10.1016/S0963-9969(02)00163-1.

Goesaert, H., Leman, P., Bijttebier, A., \& Delcour, J. A. (2009a). Antifirming effects of starch degrading enzymes in bread crumb. 
Journal of Agricultural and Food Chemistry, 57(6), 2346-2355. http:// dx.doi.org/10.1021/jf803058v. PMid:19239186

Goesaert, H., Slade, L., Levine, H., \& Delcour, J. A. (2009b). Amylases and bread firming: an integrated view. Journal of Cereal Science, 50(3), 345-352. http://dx.doi.org/10.1016/j.jcs.2009.04.010.

Griswold, R. M. (1972). Estudo experimental dos alimentos. São Paulo: Ed. Universidade de São Paulo. 469 p.

Grundy, J. G. (1996). Preservatives. In R. E. Hebeda \& H. F. Zobel (Eds.), Baked goods freshness (pp. 189-203). New York: Marcel Dekker.

Guy, R. C. E., \& Sahi, S. S. (2006). Application of a lipase in cake manufacture. Journal of the Science of Food and Agriculture, 86(11), 1679-1687. http://dx.doi.org/10.1002/jsfa.2540.

Hoseney, R. C. (1998). Principles of cereal science and technology. 2nd ed. St. Paul: American Association of Cereal Chemistry. 378 p.

Indrani, D., \& Rao, V. G. (2008). Functions of ingredients in the baking of sweet goods. In S. G. Sumnu \& S. Sahin (Eds.), Food engineering aspects of baking sweet goods (pp. 32-45). Boca Raton: CRC Press/ Taylor \& Francis Group.

Khalil, A. H. (1998). The influence of carbohydrate-based fat replacers with and without emulsifiers on the quality characteristics of lowfat cake. Plant Foods for Human Nutrition, 52(4), 299-313.

Kocer, D., Hicsasmaz, Z., Bayindirli, A., \& Katnas, S. (2007). Bubble and pore formation of the high-ratio cake formulation with polydextrose as a sugar and fat-replacer. Journal of Food Engineering, 78(3), 953964. http://dx.doi.org/10.1016/j.jfoodeng.2005.11.034.

Lagrain, B., Leman, P., Goesaert, H., \& Delcour, J. A. (2008). Impact of thermostable amylases during bread making on wheat bread crumb structure and texture. Food Research International, 41(8), 819-827. http://dx.doi.org/10.1016/j.foodres.2008.07.006.

Mathewson, P. R. (2000). Enzymatic activity during bread baking. Cereal Foods World, 45(3), 98-101.
Pyler, E. J. (1973). Bakery shortenings. In E. J. Pyler (Ed.), Baking science and technology (pp. 223-285). Kansas: Sosland Publishing.

Ronda, F., Gomez, M., Caballero, P. A., Oliete, B., \& Blanco, C. A. (2009). Improvement of quality of gluten-free layer cakes. Food Science \& Technology International, 15(2), 193-202. http://dx.doi. org/10.1177/1082013208105170.

Sablani, S. S. (2009). Gelatinization of starch. In M. S. Rahman (Ed.), Food properties handbook (pp. 287-314). 2nd ed. Boca Raton: CRC Press.

Sahi, S. S. (2008). Cake emulsions. In S. G. Sumnu \& S. Sahin (Eds.), Food engineering aspects of baking sweet goods (pp. 81-98). Boca Raton: CRC Press/Taylor \& Francis Group.

Sahin, S. (2008). Cake batter rheology. In S. G. Sumnu \& S. Sahin (Eds.), Food engineering aspects of baking sweet goods (pp. 99-117). Boca Raton: CRC Press/Taylor \& Francis Group.

Sakiyan, O., Sumnu, G., Sahin, S., \& Bayram, G. (2004). Influence of fat content and emulsifier type on the rheological properties of cake batter. European Food Research and Technology, 219(6), 635-638. http://dx.doi.org/10.1007/s00217-004-1020-4.

Şumnu, G., Ndife, M. K., \& Bayındırlı, L. (1999). Effects of sugar, protein and water content on wheat starch gelatinization due to microwave heating. European Food Research and Technology, 209(1), 68-71. http://dx.doi.org/10.1007/s002170050459.

Van der Maarel, M. J., Van der Veen, B., Uitdehaag, J. C., Leemhuis, H., \& Dijkhuizen, L. (2002). Properties and applications of starch-converting enzymes of the a-amylase family. Journal of Biotechnology, 94(2), 137-155. http://dx.doi.org/10.1016/S01681656(01)00407-2. PMid:11796168

Wilderjans, E., Pareyt, B., Goesaert, H., Brijs, K., \& Delcour, J. A. (2008). The role of gluten in a pound cake system: A model approach based on gluten-starch blends. Food Chemistry, 110(4), 909-915. http:// dx.doi.org/10.1016/j.foodchem.2008.02.079. 